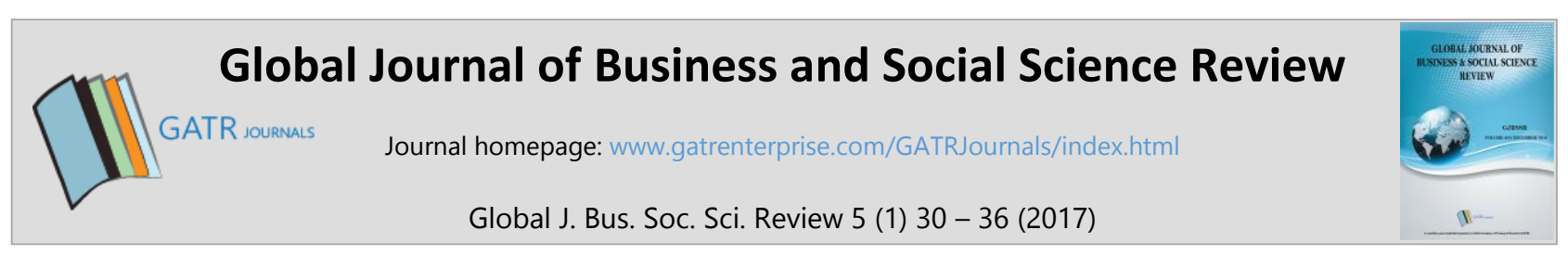

\title{
Improving Supply Chain Performance through the Implementation of Supply Flexibility
}

\author{
Meirani Harsasi* \\ Universitas Terbuka, Jl. Cabe Raya Pondok Cabe Pamulang, 15418, Tangerang Selatan, Indonesia
}

\begin{abstract}
Objective - This study aims to analyze the impact of supply flexibility on supply chain performance. The rapidly changing market demands have to be faced with a flexible supply chain management in order to reach market acceptance. The key to successful supply chain management also depends on supply flexibility; given that the smooth flow of materials and parts will define the whole manufacture operation.

Methodology/Technique - Supply flexibility consists of two variables, namely, supplier flexibility and supply network flexibility. The research was conducted by taking samples from the garment industry in Indonesia.

Findings - As a result of this research, it was found that supplier flexibility affects the supply chain performance, while supply network flexibility does not.

Novelty - The study suggests that the Indonesian garment industry needs to strengthen the cooperation network with more suppliers so that the relationship can be more flexible to ensure the availability of high quality raw materials and parts at the appropriate prices to maintain the smooth operation of the company.
\end{abstract}

Type of Paper: Empirical.

Keywords: supply chain performance; supply chain management; supply flexibility; supplier flexibility; supply network flexibility.

JEL Classification: L11, R41.

\section{Introduction}

Business nowadays is more consumer-focused; companies have to be able to deliver consumers' demands to create products that are suitable for the customers. In uncertain conditions, both from customers and suppliers, companies are trying to improve flexibility; that term can be defined as the capability to cope with changing market environments. Several companies have discovered that supply chain flexibility is now more crucial to build competitiveness, particularly within the rapidly changing market. Fashion industries, mobile phone industries or bicycle industries are in the list of industries benefitting in applying flexible supply chain (Catalan \& Kotzab, 2003; Lao et al., 2010). Efficient operation is emphasizing the ability to respond to the resources to create values amongst supply chain members. Network cooperation improvement between supply

\footnotetext{
* Paper Info: Revised: September, 2016

Accepted: January, 2017

* Corresponding author:

E-mail: rani@ut.ac.id

Affiliation: Universitas Terbuka, Indonesia
} 
chain members is aiming to strengthen coordination of the product and information flows between supply chain members, as well as improving the skill to deliver various products. This demonstrates how supply flexibility is becoming crucial, due to more complex consumer demands, along with the business environment uncertainty and supply and demand uncertainty.

These uncertain business conditions demand companies to continuously refine their supply chain strategies to be able to respond to consumer demands quickly. To be responsive in dealing with consumer demands, companies have to manage product and information flows between supply chain members, so the demand information can be accessible to the whole members of supply chain, including the suppliers. The application of information and technology has become crucial in improving the synergy in supply chains. Organizations' inter-functional collaboration and cooperation also need to be improved in order to respond to the changes of consumer demands quickly (McKone-Sweet \& Lee, 2009). Successful supply chain management is also affected by supply flexibility; securing smooth operation until the product reached end-customers. Some researchers in the field of supply flexibility showed that there are positive impact of supply flexibility on performance (Sánchez \& Pérez, 2005; Fantazy et al., 2009; Merschmann \& Thonemann, 2011; Agus, 2011). Those studies were conducted in different countries and of different research subjects. However, there are relatively few empirical studies of supply flexibility and firm performance in Indonesia, especially of the garment industry. The garment industry is one of the most important industries in Indonesia. Its ability to employ more than 1.5 million workers with a total export value reaching US\$ 3.47 billion in 2014, demonstrates that this industry serves as one of the economic driving forces in Indonesia (Indonesia Ministry of Industry, 2015). This paper seeks to verify the impact of supply flexibility in terms of supplier flexibility and supply network flexibility on performance in Indonesia using multiple regression analysis.

\section{Theoretical Background and Hypotheses Development}

\subsection{Supply Flexibility}

Supply Chain Management has been developed from operational management aspects related to the continuation of the product, service and information flow from suppliers to customers. Supply chain management emphasizes the synergy of the product flow process from supplier, manufacturer and retailer, to end customers. The principles of supply chain management are synchronization and coordination between activities that are related to raw material/product flow either within or between organizations. Supply chain management holds a crucial role in integrating external suppliers with internal operations within a company to create value for customers (Narasimhan et al., 2004).

Operation performance is highly dependent on the flow of products and information within and across supply chains. This also means that stable supply is needed during operational processes. Supply flexibility is derived from the understanding that resources can be distributed and coordinated to build particular capacities. Supply flexibility also refers to a companies' ability to respond to environmental changes by coordinating and optimizing the whole of their available resources (Lao et al., 2010). Sanchez (1995) divided supply flexibility into resources flexibility and coordination flexibility. Resources flexibility means companies' responsive ability in implementing specific company management knowledge and in deploying physical assets. Coordination flexibility is defined as responsive capability in implementing cross-functions coordination. Lao et al., (2010) has divided the concept of supply flexibility into two elements: supplier flexibility and supply network flexibility. Supplier flexibility is defined as responsive ability in deploying specific capabilities of the supplier. Companies have been emphasizing the connection between internal resources and performance so that they add values to suppliers' coordination. Competitiveness can be achieved by combining internal resources with external resources to create distinct qualities (Lavie, 2006).

Supply network flexibility is defined as a responsive ability, achieved by implementing collaborative capability to form supply network efficiency and effectiveness (Lao et al., 2010). This concept was derived from the concept of coordination flexibility and explains why leading competitors are able to be more 
responsive and achiev more advantages than the rest of their competitors. Supply network structures will also affect product and information flow within and across supply chains. Better structure, coordination and management within supply chain will allow the organization to better utilize their supply chain using optimal resources (Skilton \& Robinson, 2009). Flexibility within the supply chain leads companies to gain better performance in different aspects at once, e.g. responsiveness and cost performance. This performance can be achieved by implementing new science and technology and by reading the market changes to create and deliver values to customers.

\subsection{Supply Chain Performance}

Supply chain performance measurement is necessary to measure the success of product development and product delivery to end customers. Supply chain performance can be defined as the ability to meet the endcustomer demands and the ability to deliver on consumer demands efficiently (Hausman, 2005). This definition also means that supply chain performance can be measured by two variables, efficiency and effectiveness, and how those two variables can be optimized. This research measures supply chain performance by four variables. They are performance on timing, reliability, suppliers' performance and cost performance (Lao et al., 2010). Timing performance is measured by the ability of supply chains in responsiveness. Reliability is measured by the ability of supply chains to deliver products and services accurately. Supplier performance is measured by the suppliers whole outcomes, both the visible and invisible, including the quality of product, service reliability, and relationship and cost performance is measured by cost management effectiveness within supply chain operational.

\subsection{Hypotheses Development}

Several studies on supply chain flexibility concerning resources have been conducted. Among them are Kumar et al., (2006) and Gonzales-Benito (2007). Kumar's research has showed that delegation between suppliers and manufacturers will be beneficial to a companies ability to reach integrated flexibility. GonzalesBenito's research shows that supply chain contribution to business performance success depends on supply chain rate of progression towards business strategies. Companies that implement flexible supply chain will have the advantage of having the ability to be responsive with business environment changes. A flexible supply chain requires commitment and investment in developing suppliers' performance and suppliers' relations.

Supply flexibility has a high bearing on supply chain performance, especially in responding to rapid business environment changes. Suppliers that have flexible systems and process will be able to respond to business environment changes, leading to increasing performance in their supply chain. Flexible suppliers also have better coordination to communicate ideas, product designs, and mutual collaboration (Lao et al., 2010). Suppliers with high flexibility rates contribute better in product and services deliveries, and also have better responsiveness.

Supply network flexibility is also necessary to achieve responsive supply chains, to assure the reliability of product supply. The ability to change supply network will enable companies to quickly response the changes in business environment, as well as dynamic supplier relation. Managing the relationship needs constant improvement to secure supply chain operation.

Based on the literature review and previous research, the proposed hypotheses are:

H1: Suppliers' flexibility positively affects supply chain performance.

H2: Supply network flexibility positively affects supply chain performance.

Based on the elaborated hypothesizes and theories, the research model being proposed is as follow. 


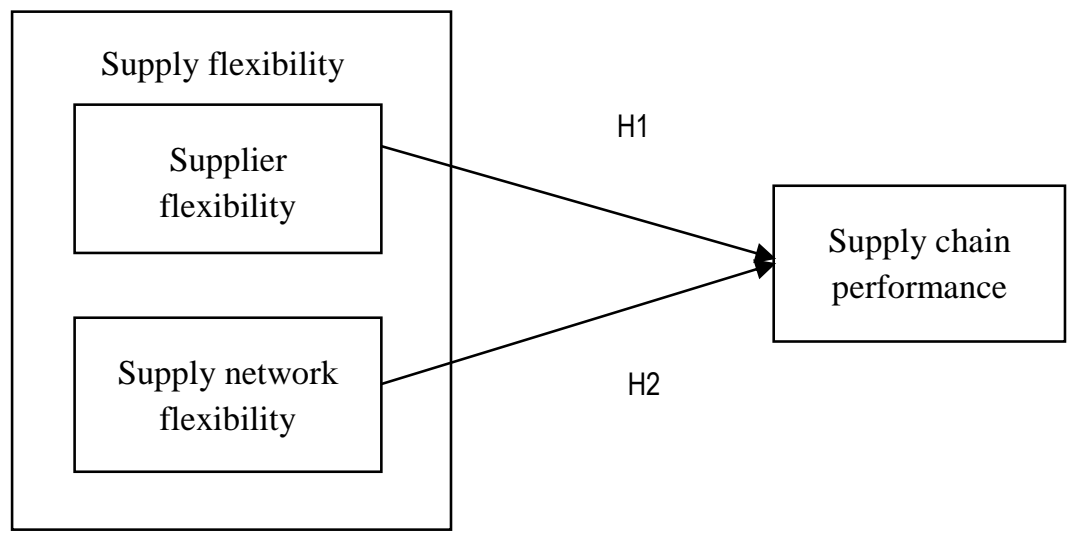

Figure 1. Research Model

\section{Methods}

We designed this study as a causal research that has been conducted to identify the causal relationship between variables of which the research problems have been clearly defined (Zikmund, 2000). This study is conducted based on previous research (Lao et al., 2010) thus the literature review and hypotheses have already been formed. Operational definitions of all variables and indicators have been formed clearly based on the previous research. The development of measurement tools of supply flexibility and supply chain performance used in this study were mostly drawn from existing scales, also found in previous research of Lao et al (2010).

The research population includes every manufacture company in Indonesia that are registered in the Directory of Manufacture Industries published by the Indonesian Central Bureau of Statistics in 2013. The sampling technique being used is purposive sampling, by using large garment companies in Indonesia which have more than 100 employees. This criterion was chosen for the reason that large companies must already have a good supply chain network, so they were able to provide the best answers and responses, suitable for the purpose of this research. The garment industry has been selected for suitability with the industrial nature of the topics studied. The garment industry must be able to respond to consumer demand quickly and so should have the flexibility for suppliers and network. The product of the garment industry by definition has a short life cycle due to the ever-changing customer demands.

The data collected is primary data gathered by questionnaires. Because this research focuses on supply chain management practices and flexibility, a set of questions were sent to operations managers by mail. Each respondent was given a set of questions. They were asked to answer every question which were measured using a 5-point Likert scale. In order to answer the hypothesis that has been determined, the data was analyzed through several stages: validity testing, reliability testing and multiple linear regression analysis.

\section{Results}

As many as 48 questionnaires were answered and returned for further analysis. The first step in analyzing the data is to test the validity using Confirmatory Factor Analysis ('CFA'). An item in question can be classified as a valid item/indicator if it has a loading factor greater than 0.4 and clustered into its group along with other items/indicators in the variable. The result shows that an acceptable convergent validity is items with factor loading more than 0.4 and significance level at 5\%. This research uses three variables: supplier flexibility, supply network flexibility and supply chain performance. Each variable has different indicators summarized in Table 1. 
Table 1. Research Variables and Indicators

\begin{tabular}{|l|l|l|}
\hline No. & Variables & Indicators \\
\hline 1 & Supplier Flexibility & $\begin{array}{l}\text { Supplier Flexibility no. 1 and Supplier } \\
\text { Flexibility no. 2 }\end{array}$ \\
\hline 2 & Supply Network Flexibility & $\begin{array}{l}\text { Supply Network Flexibility no. 1 - Supply } \\
\text { Network Flexibility no. 4 }\end{array}$ \\
\hline 3 & Supply Chain Performance & $\begin{array}{l}\text { Supply Chain Performance no. 1 - Supply } \\
\text { Chain Performance no. 2 }\end{array}$ \\
\hline
\end{tabular}

The results of the CFA shows that every indicator is valid, with a factor loading value greater than 0.4 and grouped into each grouping variable. Factor analysis results shown in Table 2.

Table 2. Factor Analysis Results

\begin{tabular}{|l|c|c|c|c|}
\hline Indicator & Component 1 & Component 2 & Component 3 & Remarks \\
\hline FJP 1 & & .870 & & valid \\
\hline FJP 2 & & .532 & & valid \\
\hline FJP 3 & & .875 & & valid \\
\hline FJP 4 & & .610 & & valid \\
\hline FP 1 & & & .851 & valid \\
\hline FP 2 & & & .853 & valid \\
\hline K1 & .843 & & & valid \\
\hline K2 & .859 & & & valid \\
\hline K3 & .880 & & & valid \\
\hline K4 & .787 & & & valid \\
\hline K5 & .878 & & & valid \\
\hline K6 & .838 & & & valid \\
\hline K7 & .881 & & & valid \\
\hline K8 & .842 & & & valid \\
\hline
\end{tabular}

The next step is to test the reliability for each variable by using Cronbach's Alpha coefficient and item-tototal correlation to fix the examination by eliminating unnecessary points that would be reducing Cronbach's Alpha. The examination resulting from Cronbach's Alpha value for each construct is higher than 0.60, and have therefore satisfied the reliability test. The value of Cronbach's Alpha of each variable as presented in Table 3.

Table 3. The Result of Reliability Test

\begin{tabular}{|l|c|c|}
\hline \multicolumn{1}{|c|}{ Variable } & $\begin{array}{c}\text { Cronbach's Alpha Based Value } \\
\text { on Standardized Items }\end{array}$ & Remarks \\
\hline Supplier flexibility & .805 & Reliable \\
\hline Supply network flexibility & .713 & Reliable \\
\hline Supply chain performance & .954 & Reliable \\
\hline
\end{tabular}

The hypotheses examination used in this study is multiple linear regressions with supplier flexibility and supply network flexibility as the independent variables, and supply chain performance as the dependent variable. Using the statistical model of multiple regressions on SPSS version 17, we can obtain the value as estimation parameter, multiple correlation coefficient $(\mathrm{R})$, and multiple determinant coefficient $\left(\mathrm{R}^{2}\right)$. Regression coefficient has also obtained for each independent variable. This research uses $0.05 \alpha$, which brings 
the confidence level to $95 \%$. According to the limitations, if $\mathrm{p}$ value is $\leq 0,05$, the independent variable significantly affects the dependent variable, where the level of confidence is $95 \%$ and permits $5 \%$ of a maximum deviation rate, while R-squared $\left(\mathrm{R}^{2}\right)$ shows how much fluctuation changes in the value of dependent variable is derived from independent variables. For more details, the result of multiple regression analysis as presented in Table 4.

Table 4. The Result of Multiple Regression Analysis

\begin{tabular}{|l|c|c|c|c|}
\hline \multicolumn{1}{|c|}{ Independent Variables } & $\begin{array}{c}\text { Dependent } \\
\text { Variable }\end{array}$ & Coefficient & $\mathrm{t}$ & Sig t \\
\hline Supply chain flexibility & $\begin{array}{c}\text { Supply chain } \\
\text { performance }\end{array}$ & 0.407 & 3.179 & 0.003 \\
\hline Supply network flexibility & & -0.189 & -1.479 & 0.146 \\
\hline $\mathrm{R}^{2}$ & & & 0.198 \\
\hline Adjusted $\mathrm{R}^{2}$ & & 0.165 \\
\hline $\mathrm{F}$ & & 6.037 \\
\hline Sig F
\end{tabular}

Table 4 shows that the supplier flexibility variable positively affects supply chain performance. However, the supply network flexibility variable does not affect supply chain network. The adjusted $\mathrm{R}^{2}$ value in this model is also very low (0.165). This shows that supplier flexibility can explain supply chain performance variation to an extent of $16.5 \%$. The other of $83.5 \%$ is influenced by other factors that are not being researched. Whilst determining the model significance, the value of F is 6.037 with 0.005 probability. Since it is less than a 0.05 probability, the regression model can be used to predict supply chain performance using supply chain flexibility variable.

\section{Discussion}

This study sought to analyze the impact of supply flexibility on firm performance. The results support some previous studies; Sánchez \& Pérez, 2005; Fantazy et al., 2009; Merschmann \& Thonemann, 2011; Agus, 2011. This research focused on supplier-buyer relationships to configure supply flexibility. Supplier flexibility is proven as a variable that supports firm performance directly. There are also some external and internal drivers to increase supply chain flexibility in a business. External drivers relate to demand volatility and seasonality whereas internal drivers relate to low commonality between products and product schedule uncertainty (Kopecka et al., 2009). However, supplier-buyer relationships also affect the importance of how a firm collaborates with its clients. This relationship can be described as 'sourcing' and 'supply'. The former refers to the ability of a firm to choose and change suppliers on the basis of supplier performance. This theory underlying the research results in Indonesia found that supply network flexibility doesn't affect firm performance. Based on the research instruments, supply network flexibility is measured by the number of suppliers as well as producers capability to replace the suppliers within the network if one of the suppliers does not perform well. Garment companies in Indonesia only build networks with suppliers based on trust and convenience in developing a close relationship. It promotes a view that garment companies in Indonesia are highly dependent on only a small number of suppliers, so as to improve the smoothness of operations. Another result showed that supplier flexibility positively affect on performance. According to Lao et al., (2010), supplier flexibility is one of the variables affecting supply chain performance, specifically in facing competitive and rapidly-changing business environment. Suppliers with flexible system and process have the ability to respond to changes in business environment, which enhances supply chain performance. Flexible suppliers also have better coordination and communication to deliver ideas, product designs, and mutual collaboration. Suppliers with high flexibility rates contribute better to product and service delivery as well as having better responsiveness. 


\section{Conclusions}

This study aims to analyze the effect of supply chain flexibility on supply chain performance. Data was gathered by sending questionnaires to garment companies in Indonesia, with 48 questionnaires being returned for further analysis. This study provides empirical evidence of the effect of supply flexibility on performance. The results show that supply network flexibility does not affect firm performance. Therefore, the Indonesian garment industry needs to strengthen the cooperation network with more suppliers so as to increase flexibility in their choice of suppliers to ensure the availability of high quality raw materials and parts at the appropriate prices, thereby maintaining smooth operations. Another result showed that supply flexibility has positive impact on performance. This further supports the former result that garment companies are highly dependent on several suppliers. In taking the positive side from this condition, it is shown that garment companies need to strengthen their relationships with suppliers in the form of a higher commitment as well as supplier selection.

\section{References}

Agus, A. (2011) Supply clChain Management, Supply Chain Flexibility and Business Performance. Journal of Global Strategic Management, 9, $134-145$.

Catalan, M and Kotzab, H. (2003) Assessing the Responsiveness in the Danish Mobile Phone Supply Chain. International Journal of Physical Distribution \& Logistics Management, 33(8), 669-685.

Fantazy, K.A., Kumar, V., and Kumar,U. (2009) An Empirical Study of the Relationships Among Strategy, Flexibility, and Performance in the Supply Chain Context. Supply Chain Management: An International Journal, 14(3), 177 -188 .

Gonzales-Benito, J. (2007) A theory of Purchasing Contribution to Business Performance. Journal of Operations Management, 25(4), 901-917.

Hausman, W., H. (2005) Supply Chain Performance Metric. The Practice of Supply Chain Management. New York: Springer Science \& Business Media, Inc.

Indonesia Ministry of Industry. (2015). Available online at http://www.kemenperin.go.id/artikel/ 12920/Menperin:Industri-Garmen-Agresif-Berekspansi-dan-Jalin-Mitra-Luar-Negeri.

Kopecka, J., Penners, G., and Santema, S. (2009). Flexibility in supply chain management. Paper published at the $25^{\text {th }}$ IMP-conference in Marseille, France. Available online at http://www.impgroup.org/paper_view.php?viewPaper=7315.

Kumar, V., Fantazy, K.A., Kumar, U., dan Boyle, T.A. (2006) Implementation and Management Framework for Supply Chain Flexibility. Journal of Enterprise Information Management, 19(3), 303-319.

Lao, Y., Hong, P., dan Rao, S.S. (2010). Supply Management, Supply Flexibility, and Performance Outcomes: An Empirical Investigation of Manufacturing Firms. Journal of Supply Chain Management, 46 (3), 6-22.

Lavie, D. (2006) The Competitive Advantage of Inter Connected Firms: An Extension of the Resource-based view. The Academy of Management Review, 31(3), 638-658.

McKone-Sweet, K., dan Y.T. Lee. (2009) Development and Analysis of a Supply Chain Strategy Taxonomy. Journal of Supply Chain Management, 45(3), 3-24.

Merschmann, U. and Thonemann, U.W. (2011) Supply Flexibility, Uncertainty and Firm Performance: An Empirical Analysis of German Manufacturing Firms. International Journal of Production Economics, 130(1), 43-53.

Narasimhan, R., Talluri, s., dan Das, A. (2004). Exploring Flexibility and Execution Competencies of Manufacturing Firms. Journal of Operation Management, 22(1), 91-106.

Sanchez, R. (1995) Strategic Flexibility in Product Competition. Strategic Management Journal, 16(5), 135-159.

Sánchez, A.M., and Pérez, M.P., (2005) Supply Chain Flexibility and Firm Performance: A Conceptual Model and Empirical Study in the Automotive Industry. International Journal of Operations \& Production Management, 25 (7), 681-700.

Skilton, P., F., dan Robinson, J., L. (2009). Traceability and Normal Accident Theory: How does Supply Network Complexity influence the Traceability of Adverse Events? Journal of Supply Chain Management, 45(3), 40-53.

Zikmund, W.G. (2000). Business Research Methods, 6th ed.). The Dryden Press. 